\title{
Fullt upp från morgon till kväll
}

\author{
Kajsa Ellegård
}

Linköping University Post Print

N.B.: When citing this work, cite the original article.

Original Publication:

Kajsa Ellegård, Fullt upp från morgon till kväll, 2014, Venue, 2014.

Copyright: The author

http://www.liu.se/uv/lararrummet/venue?l=sv

Postprint available at: Linköping University Electronic Press

http://urn.kb.se/resolve?urn=urn:nbn:se:liu:diva-113951 


\section{Fullt upp från morgon till kväll}

\section{Kajsa Ellegård, Tema teknik och social förändring, Temainstitutionen, Linköpings universitet}

Grundskollärare har långa arbetsdagar, i genomsnitt cirka 9,5 timmar. Men genomsnittstiden säger inte mycket om hur dagarna ser ut, när olika arbetsaktiviteter genomförs under dagen, hur länge de varar, om de splittras upp av annat, om några aktiviteter är mer vanliga hos vissa lärare än andra eller hur fördelningen mellan arbetet på skolan eller i hemmet ser ut. En ökad kunskap om lärares tidsanvändning visar den komplexitet som följer med skolans vardag och möjliggör nya vägar att hantera den.

\section{Lärares tidsanvändning}

Många olika faktorer präglar lärares arbetsmiljö. En rör hur deras tid används för olika arbetsaktiviteter och Skolverket genomförde en tidsanvändningsundersökning under vårterminen 2012 för att ta reda på hur det ser ut. Totalt 3626 grundskollärare fyllde i tidsdagböcker under en dag var, fördelat över hela terminen. Resultaten finns publicerade i två studier; "Lärarnas yrkesvardag. En nationell kartläggning av grundskollärares tidsanvändning" (Skolverket 2013a) som ger en generaliserad bild av den genomsnittliga tidsanvändningen i den svenska grundskolan, och "En tidsgeografisk studie av strukturen i lärares vardag" (Skolverket 2013b) som använder samma dagboksmaterial och visar när, var och hur länge lärarna använde sin tid till olika arbetsaktiviteter. Den sistnämnda studien ligger till grund för den här artikeln.

Undervisning, som är den tidsmässigt dominerande aktiviteten, är strikt schemalagd, Andra arbetsaktiviteter utförs i en viss ordning i förhållande till undervisningen, exempelvis planering av undervisning respektive uppföljning och bedömning av elevers kunskapsutveckling. Åter andra aktiviteter måste genomföras när det behövs, som till exempel att skapa arbetsro i eller ordning utanför klassrummet.

Den komplexitet som karaktäriserar lärarnas vardag kommer inte fram i undersökningar som enbart redovisar den genomsnittliga tidsanvändningen. De visar att lärare arbetar långa arbetsdagar, men det framgår också att sådana aktiviteter som lärare brukar säga är tidskrävande inte tar så stor andel av arbetstiden i anspråk. Undervisning tar i genomsnitt 34 procent av arbetstiden medan till exempel administrativt arbete och aktiviteter för att skapa arbetsro i klassrummet bara tar 3 procent. Att ge omsorg och skapa ordning utanför klassrummet tar 6 procent av tiden (Skolverket 2013a). Hur kan det komma sig att de sistnämnda arbetsuppgifterna ändå upplevs som tidskrävande? 


\section{VENUE}

Här kan ett kompletterande sätt att se på tidsanvändning ge svar, där alla arbetsaktiviteter sätts in i det tidsmässiga flödessammanhang som de uppträder i under dygnet. Flödet av aktiviteter under olika veckodagar visualiseras utifrån en tidsgeografisk metod och visar det vi kallar den kontextuella tidsanvändningen. (Hägerstrand 1985, Ellegård 1999, Vrotsou 2010)

\section{Genomsnittlig och kontextuell tidsanvändning}

Den genomsnittliga tidsanvändningen kan redovisa resultat som är representativa för den grupp som ingår i undersökningen. Det ger en bra och övergripande bild av läget. Men det är inte många som utbrister: "Ja, precis så är det!" Jag tror att det beror på att det fattas en viktig sak i genomsnitten, nämligen dagens rytm som visar hur de olika aktiviteterna flätas in i varandra under dagen. I figur 1 finns ett starkt förenklat exempel där fyra aktiviteter (förvärvsarbete, sömn, måltider/fika och andra aktiviteter) exemplifierar skillnaden mellan genomsnittlig och kontextuell tidsanvändning.

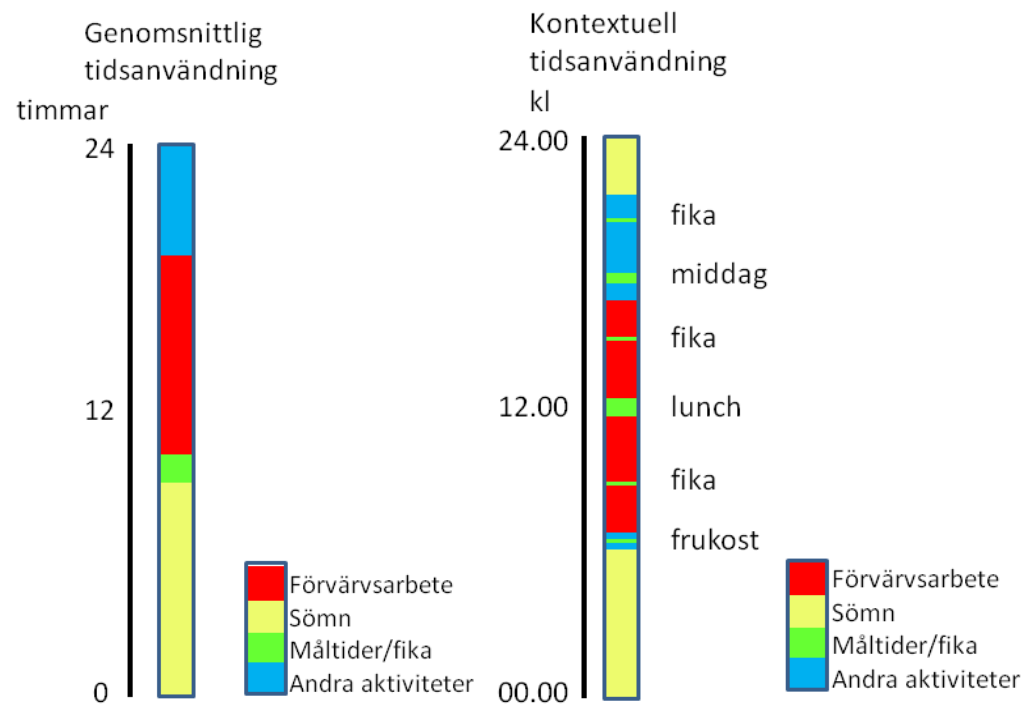

Figur 1. Principiell visualisering av genomsnittlig tidsanvändning (till vänster) och kontextuell tidsanvändning (till höger) för fyra aktivitetskategorier. Totalt används lika mycket tid åt de fyra aktiviteterna i båda visualiseringarna.

Den genomsnittliga tidsanvändningen innebär att tiden för alla separata förekomster av en aktivitet under arbetsdagen adderats till en summa timmar och minuter. Därmed försvinner växlingen mellan aktiviteter under dagen. I den kontextuella tidsanvändningen är just växlingen, vardagens rytm, grunden för att visualisera vardagens komplexitet.

När många personers tidsanvändning ska visas med hjälp av den kontextuella tidsanvändningen ställer man avbildningarna av de enskilda personernas kontextuella tidsanvändning bredvid varandra och då framträder ett samlat aktivitetsmönster. Detta mönster anger tidsanvändningens struktur i den grupp som studeras, se figur 2. 


\section{VENUE}

$\mathrm{kl}$

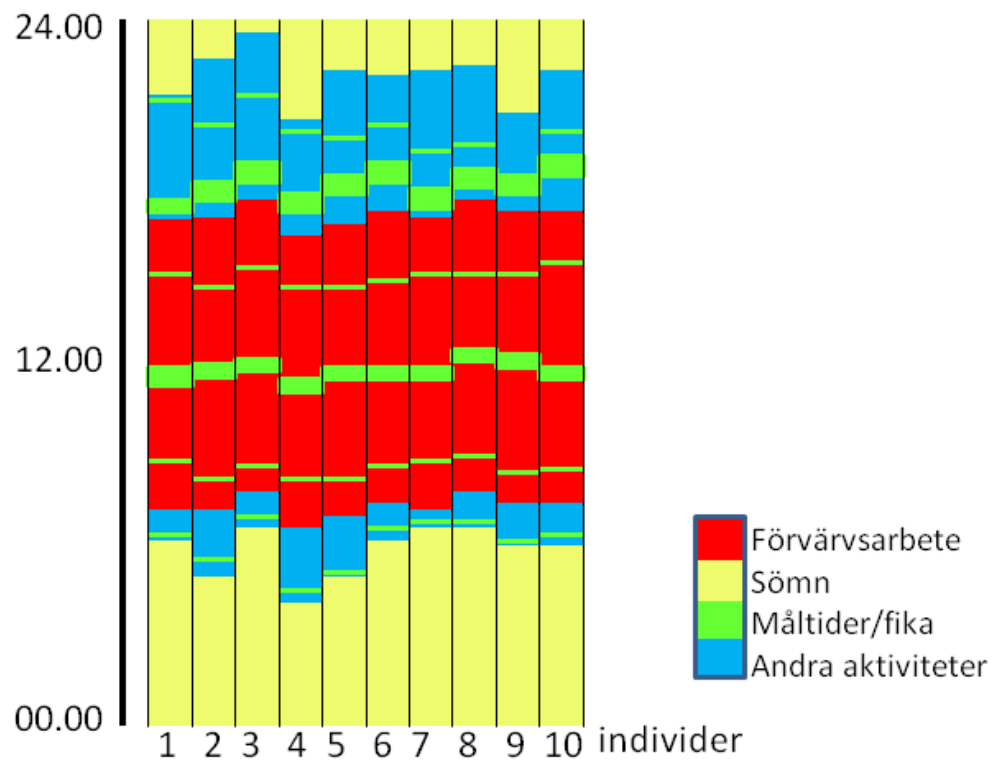

Figur 2. Det samlade aktivitetsmönstret hos en grupp av 10 individer vars kontextuella tidsanvändning redovisas bredvid varandra. Alla 10 genomför de fyra aktiviteterna i samma flödesordning, men vid lite olika tillfällen under dygnet. Fika- och lunchrasterna är här de aktiviteter som tidsmässigt är förlagda mest likartat om man både tänker på när de utförs och hur länge de pågår.

I en bild av den kontextuella tidsanvändningens samlade aktivitetsmönster hos lärare framgår arbetsdagens grundläggande rytm. Då kan besvärliga kombinationer av arbetsaktiviteter identifieras och hanteras. För att identifiera åtgärder som kan förbättra lärares arbetssituation behövs kunskap om när aktiviteterna uppträder från morgon till kväll, och då är den kontextuella tidsanvändningen en användbar utgångspunkt.

I det samlade aktivitetsmönstret kan enskilda aktiviteter analyseras var för sig, till exempel undervisning eller skapa arbetsro i klassrummet. 


\section{VENUE}

\section{Arbetsaktiviteter skapar en rytm i dygnet}

Utifrån noteringarna i grundskollärarnas tidsdagböcker framgår att det samlade aktivitetsmönstret ser ganska likartat ut från måndag till torsdag. På fredag skiljer sig aktivitetsmönstret på ett tydligt sätt: lärarna slutar genomföra arbetsaktiviteter tidigare på dagen. (Skolverket 2013b)

I figur 3 framgår det samlade aktivitetsmönstret på tisdag och fredag: oavsett årskurs börjar lärarna utföra arbetsaktiviteter cirka 7.30 alla dagar och de slutar cirka 16 på tisdagar och cirka 15 på fredagar. Det framgår också att betydligt färre lärare utför arbetsaktiviteter på fredagskvällar än på tisdagskvällar. Lärarnas tisdagar är strukturerade i fem delar: privata aktiviteter fram till cirka 7.30, därefter arbetsaktiviteter till cirka 16, följt av privata aktiviteter till cirka 19/20 och sedan åter arbetsaktiviteter fram till cirka 21/22 och till slut åter privata aktiviteter. På kvällstid varierar varaktigheten mycket. På fredag utför betydligt färre lärare arbetsaktiviteter på kvällen än på tisdag.

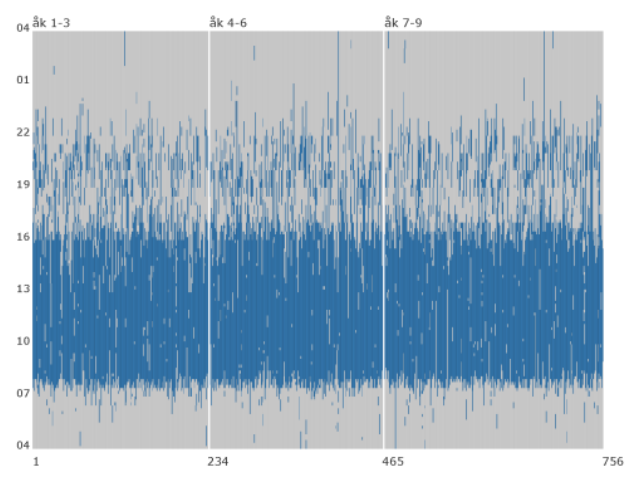

tisdag
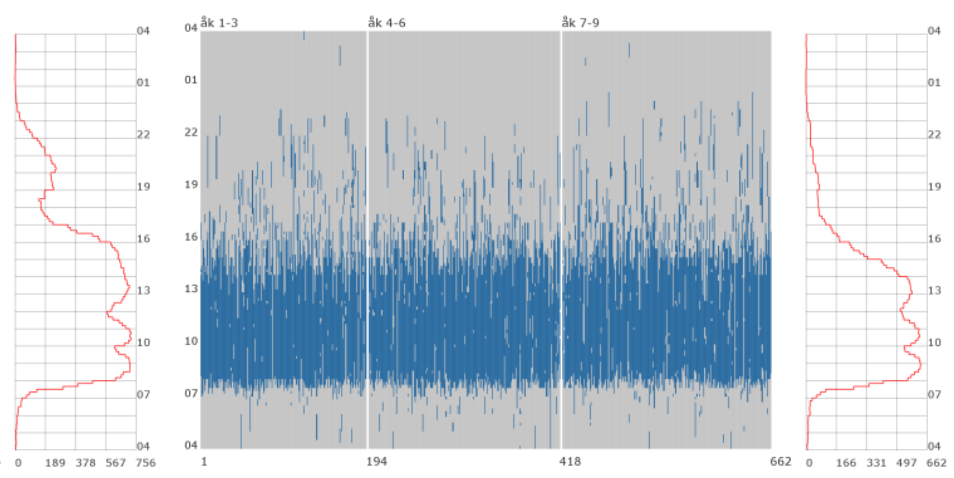

fredag

Figur 3. Grundskollärares arbetsaktiviteter (blå) under dygnet: den kontextuella tidsanvändningen i det samlade aktivitetsmönstret. Tisdagar till vänster (756 lärares dagböcker) och fredagar till höger (662 lärares dagböcker) Lärarna grupperas i årskursgrupperna 1-3, 4-6 och 7-9 separat från varandra men i samma bild. Bredvid det samlade aktivitetsmönstret finns en samtidighetsgraf som visar hur många lärare som vid samma tid utför arbetsaktiviteter under hela dagen.

\section{Arbete i skolan - och hemma}

Lärarna utför i ytterst liten utsträckning arbetsaktiviteter i skolan på kvällen. Figur 4 visualiserar när lärarnas befinner sig i skolan på tisdagar och fredagar. Där framgår att lärarna vistas längre tid i skolan på tisdagar än på fredagar och att de i huvudsak vistas i skolan nästan lika länge oavsett vilken årskurs de undervisar i. 


\section{VENUE}

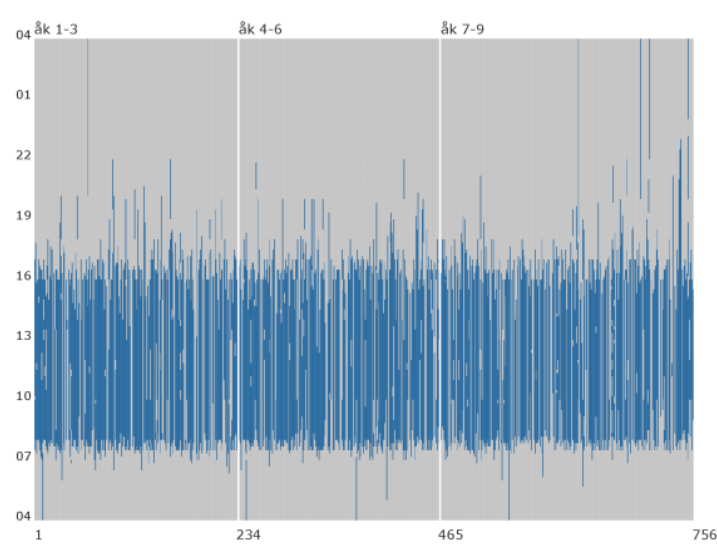

tisdag

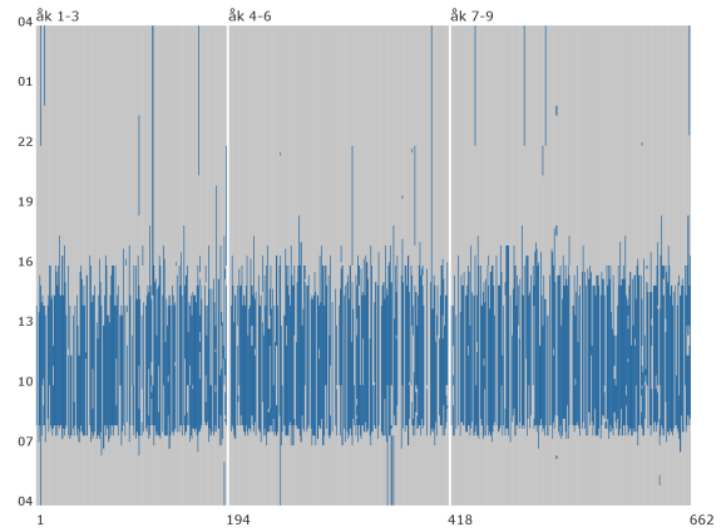

fredag

Figur 4. Lärare i alla årskursgrupper vistas längre tid i skolan (blå) på tisdagar än på fredagar. Lärarna grupperas i årskursgrupperna 1-3, 4-6 och 7-9 separat från varandra men i samma bild.

\section{Några arbetsaktiviteter i lärares arbetsvardag}

Vilka arbetsaktiviteter tar då mest tid i anspråk av lärarna och när och var utförs de? De fyra arbetsaktiviteter som tar mest tid i anspråk för lärare är desamma på tisdagar och fredagar. Förutom undervisning är det praktiska sysslor, ensam planera undervisning, omsorg och ordning utanför klassrummet samt att skapa arbetsro i klassrummet.

\section{Undervisning ensam}

Undervisning upptar mest tid och förekommer i stort sett lika mycket och under samma tid på tisdagar (se figur 5) och fredagar. Här framgår skillnader mellan lärare i de olika årskursgrupperna. Dels har elever i årskurs 1-3 färre lektionstimmar än elever i årskurs 4-6 som i sin tur har färre lektionstimmar än elever i årskurs 7-9 och detta påverkar förstås lärarnas tid för undervisning. Dels har lärare i årskurserna 1-3 och 4-6, som är klasslärare, två tydliga avbrott i sin undervisning för elevernas båda längre raster, dels strax före klockan 10 och sedan också lunchrasten. För lärare i årskurs 7-9 kan man se en antydan till lunchrast, men i övrigt har de, som är ämneslärare, undervisning i olika klasser med olika scheman.
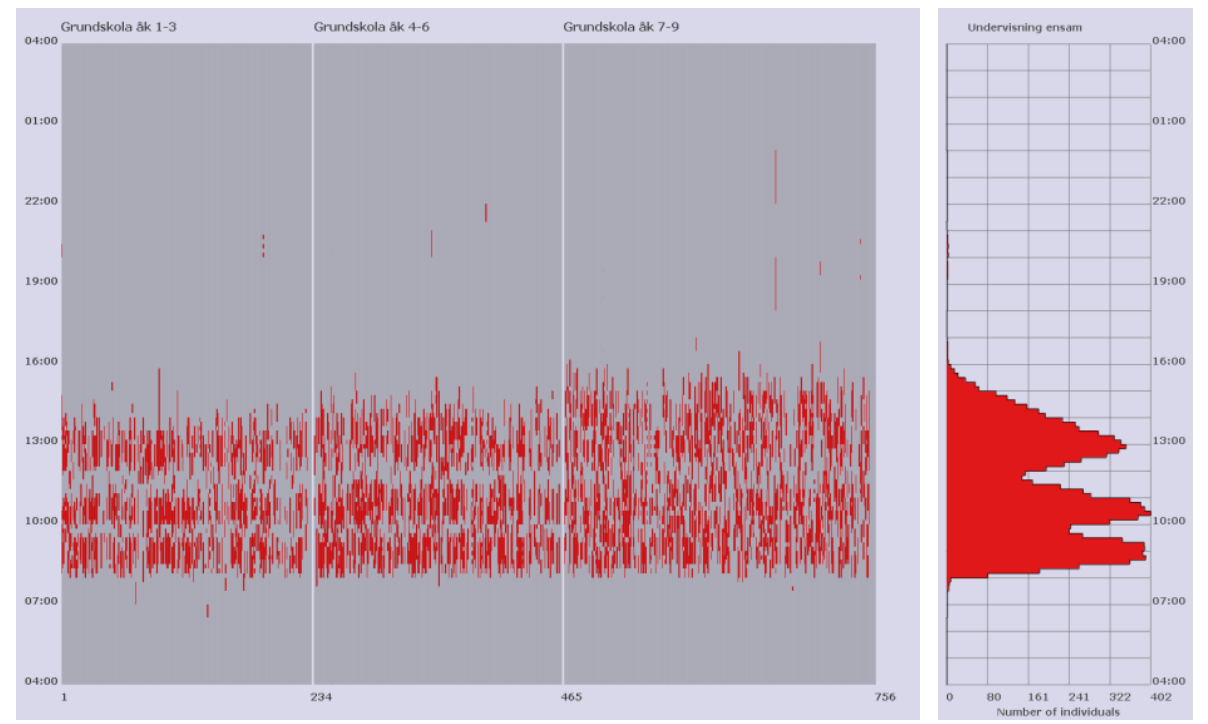


\section{VENUE}

Figur 5. Undervisning (ensam) på tisdagar (röd). Lärarna grupperas i årskursgrupperna 1-3, 4-6 och 7-9 separat från varandra men i samma bild. Bredvid det samlade aktivitetsmönstret för undervisning finns en samtidighetsgraf som visar hur många lärare som vid samma tid utför arbetsaktiviteter under hela dagen. Som mest undervisar 402 av de 756 lärarna vid samma tid.

\section{Praktiska sysslor}

Det var lite förvånande att lärarnas praktiska sysslor upptar så stor del av deras arbetstid att det är en av de fyra mest tidskrävande aktiviteterna. De allra flesta förekomsterna av praktiska sysslor är mycket kortvariga, särskilt de som genomförs under elevernas skoldag. I figur 6 framgår att många lärare börjar sin arbetsdag i skolan med praktiska sysslor och det är särskilt markerat bland klasslärarna i årskurserna 1-3 och 4-6. I övrigt är de praktiska sysslorna jämnt spridda över dagen - och bland lärarna.
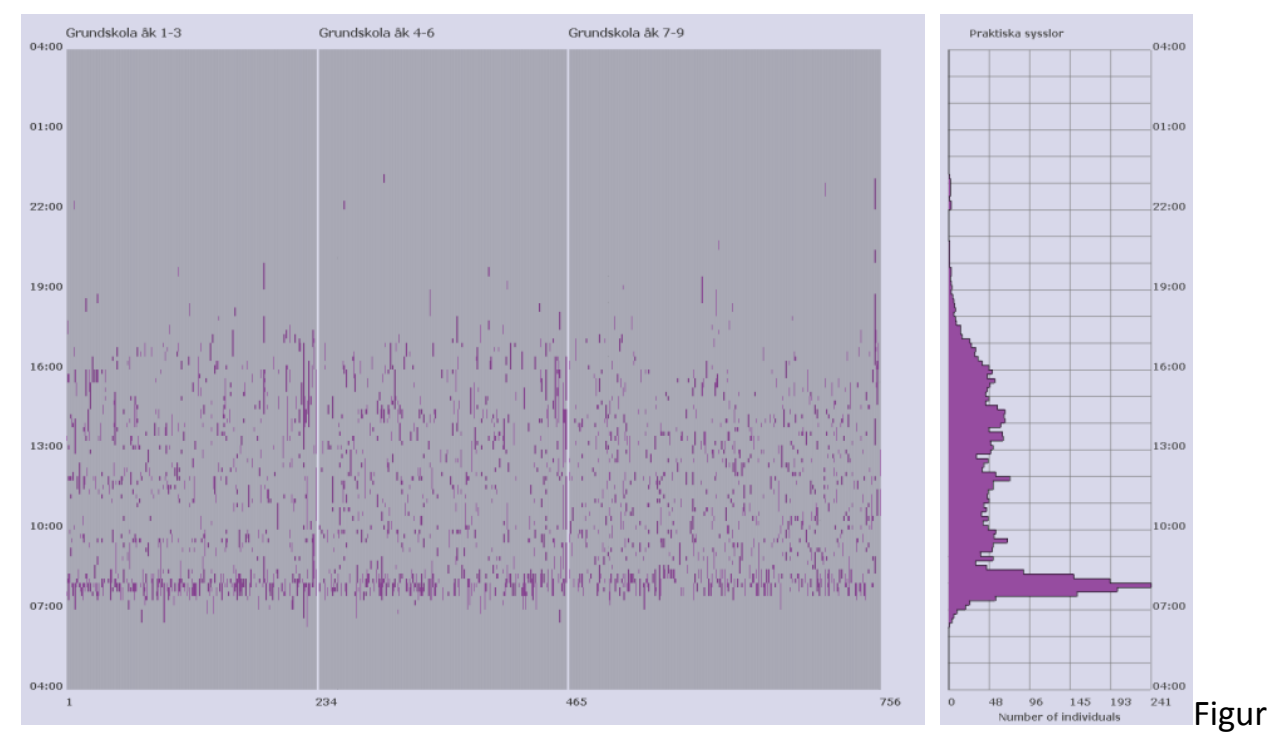

Figur 6. Praktiska sysslor, tisdag (lila). Lärarna grupperas i årskursgrupperna 1-3, 4-6 och 7-9 separat från varandra men i samma bild. Bredvid det samlade aktivitetsmönstret för praktiska sysslor finns en samtidighetsgraf som visar hur många lärare som vid samma tid utför arbetsaktiviteter under hela dagen.

\section{Ensam planering av undervisning}

Till skillnad från praktiska sysslor är ensam planering av undervisning spridd över nästan hela dygnet och vid tre tillfällen på dagen är det många lärare som utför ensam planering samtidigt (men alltså inte tillsammans). Det är på morgonen innan undervisningen börjar, på eftermiddagen före hemgång och slutligen på kvällen. På eftermiddag och kväll är varaktigheten i allmänhet längre än tidigare på dagen. Detta är en av de arbetsaktiviteter som dominerar kvällsarbetet och som alltså inte utförs i skolan, utan mestadels hemma (jämför figur 4). På fredagar utför lärarna inte särskilt mycket ensam planering hemma. 


\section{VENUE}
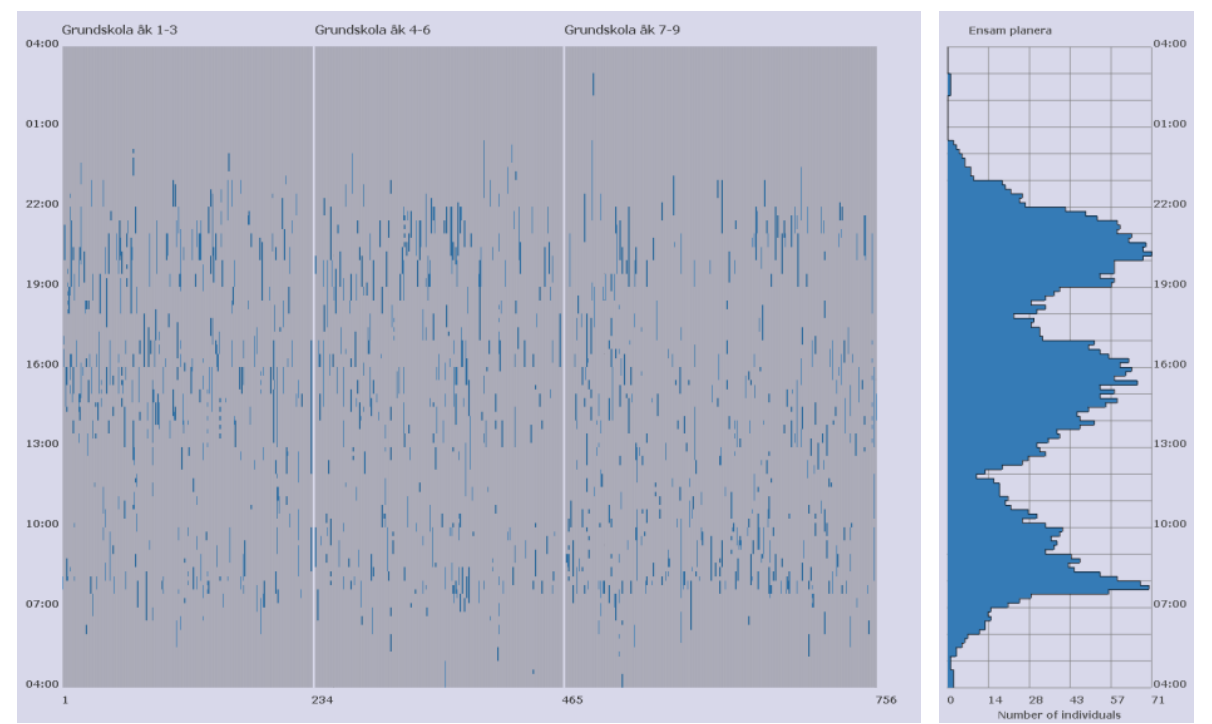

Figur 7. Ensam planera all form av undervisning, tisdagar (blå). Lärarna grupperas i årskursgrupperna 1-3, 4-6 och 7-9 separat från varandra men i samma bild. Bredvid det samlade aktivitetsmönstret för ensam planering finns en samtidighetsgraf som visar hur många lärare som vid samma tid utför arbetsaktiviteter under hela dagen.

\section{Omsorg och ordning utanför klassrummet}

Den fjärde mest tidskrävande aktiviteten, omsorg och ordning utanför klassrummet, är mycket tydligt tids- och årskursbunden. Fler lärare i årskurs 1-3 än i årskurs 4-6, och fler i årskurs 4-6 än i årskurs 7-9 utför aktiviteten. Aktiviteten innebär huvudsakligen att vara rastvakt. Lärare i årskurs 1-3 har rastvaktsaktiviteter både under den korta och den längre rasten och för alla årskurser finns en koncentration till lunchrasten. Här finns ett tydligt konkurrensförhållande mellan åtminstone två olika arbetsrelaterade aktiviteter: omsorg och ordning utanför klassrummet (rastvakt) och återhämtning under arbetsdagen. Det är två aktiviteter som båda måste ske när eleverna har rast. Återhämtning kan också ske efter det att undervisningen är slut för dagen.
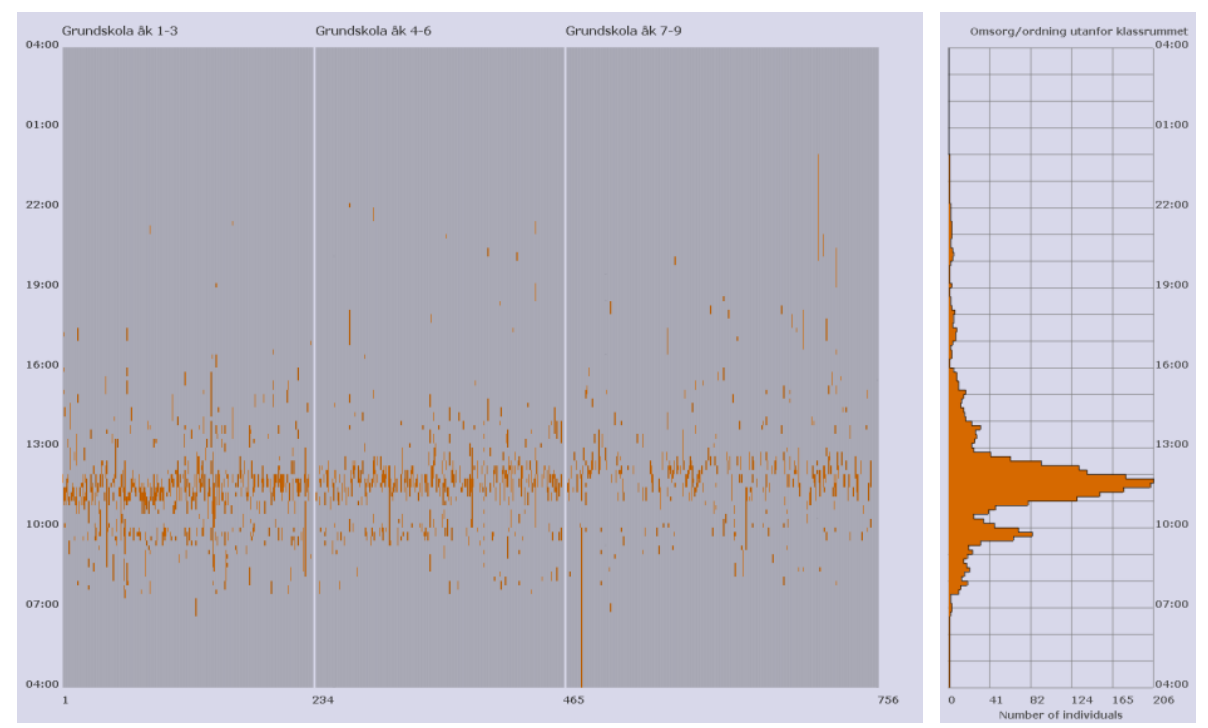


\section{VENUE}

Figur 8. Omsorg och ordning utanför klassrummet (ljusbrun). Lärarna grupperas i årskursgrupperna 1-3, 4-6 och 7-9 separat från varandra men i samma bild. Bredvid det samlade aktivitetsmönstret för omsorg och ordning utanför klassrummet finns en samtidighetsgraf som visar hur många lärare som vid samma tid utför arbetsaktiviteter under hela dagen.

\section{Skapa arbetsro i klassrummet}

För att undervisningen ska få önskad effekt på elevernas kunskapsutveckling behövs arbetsro. Ungefär hälften av alla grundskollärare ägnar sig dagligen åt att skapa arbetsro i klassrummet någon gång på tisdagar. Det är oftast mycket, kortvariga förekomster (cirka 10 minuter) och det finns ett tydligt mönster över dagen och skillnader mellan årskurser. Lärarna i årskurs 1-3 och 4-6 ägnar sig mest åt att skapa arbetsro på morgonlektionerna och sedan, framför allt i årskurs 1-3, också efter de båda längre rasterna. Det verkar finnas mycket energi hos elever som behöver kanaliseras om till skolaktiviteter. I årskurs 7-9 är aktiviteterna jämnare spridda över hela skoldagen. Lärare i alla årskurser måste också avbryta lektioner för att skapa arbetsro.

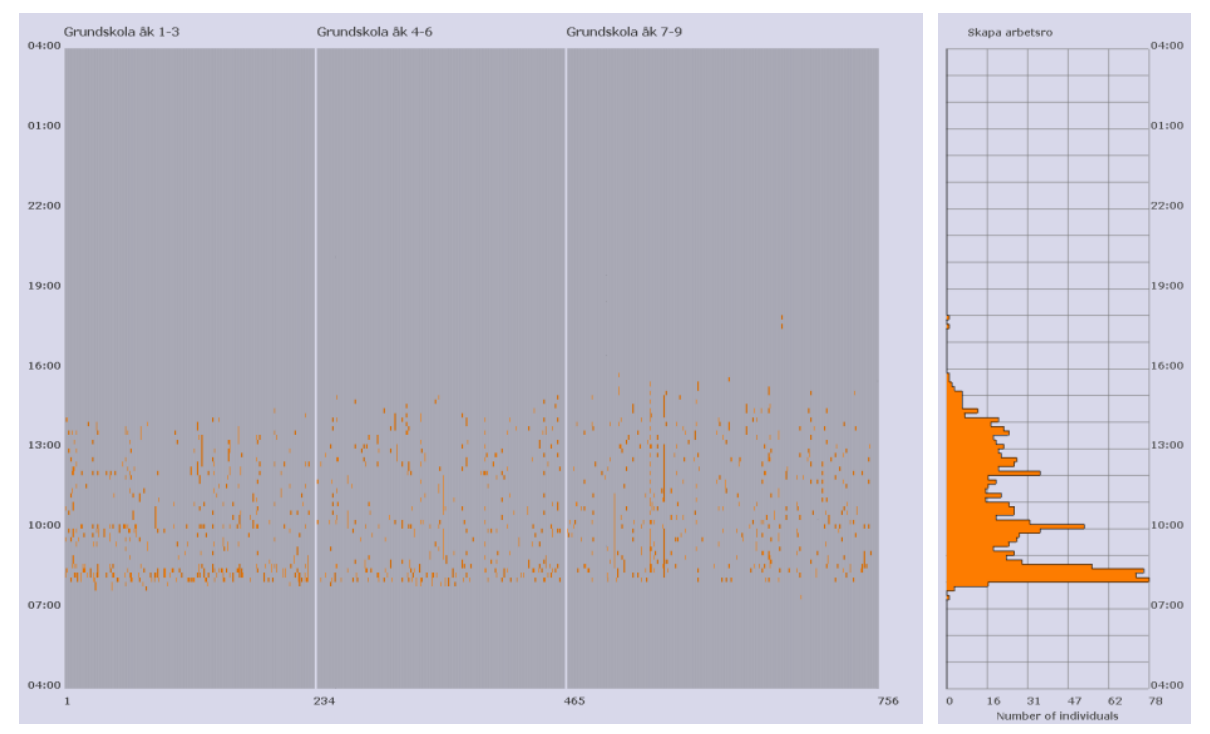

Figur 9. Skapa arbetsro i klassrummet, tisdag (orange). Lärarna grupperas i årskursgrupperna 1-3, 4-6 och 7-9 separat från varandra men i samma bild. Bredvid det samlade aktivitetsmönstret för skapa arbetsro i klassrummet finns en samtidighetsgraf som visar hur många lärare som vid samma tid utför arbetsaktiviteter under hela dagen.

Är det någon skillnad mellan lärare som varit olika länge i yrket när det gäller denna aktivitet? Vi undersökte detta närmare och fann att det är stor skillnad och att längre tid i yrket innebär avsevärt mycket mindre inslag av att skapa arbetsro i klassrummet under resten av skoldagen efter det att morgonens arbetsro skapats. Ändå fanns det strukturella mönstret med en tydlig koncentration av att skapa arbetsro i

klassrummet på morgonen hos både dem som varit lång och kort tid i yrket. Den största skillnaden är att lärare med kort yrkeserfarenhet upprepar aktiviteten flera gånger under dagen. 


\section{VENUE}

\section{Arbetet i vardagslivet - arbetsaktiviteterna påverkar det privata livet}

Lärarna har olika arbetstidsavtal, där ferieanställning innebär att läraren förväntas utföra mer arbete under terminstid än de som har semesteranställning. Feriearbetstid innebär således att längre tid per dag ägnas åt förvärvsarbetet under terminen. Som framgått ovan utförs en del av detta arbete i hemmet och på kvällen. Därigenom påverkar lärares arbete i hög grad deras privatliv, jämfört med andra yrkesgrupper. Det blir någon/några timmar på kvällen då läraren exempelvis planerar sin undervisning eller rättar prov och därför inte kan umgås med sin familj eller delta i gemensamma privata aktiviteter.

Med några tidsgeografiska begrepp kan man säga att skolan driver ett organisationsprojekt vars mål är att eleverna ska uppnå en kunskapsnivå som gör att de senare kan försörja sig i vuxenlivet och därmed bidra till samhällets utveckling. För att nå målet med skolans organisationsprojekt anställs lärare för att utföra de arbetsaktiviteter som ingår i deras yrke. Lärarens hushåll driver också organisationsprojekt men med det övergripande målet att hushållsmedlemmarna ska kunna leva ett gott liv. Ett medel för att nå detta mål är att de vuxna hushållsmedlemmarna förvärvsarbetar, någon kanske som lärare. Förvärvsarbete är ett exempel på ett individprojekt. Ett av lärarens mål med individprojektet förvärvsarbete är att erhålla inkomst, ett annat mål för många lärare är att uppnå tillfredsställelsen att se elevernas kunskaper utvecklas. Skolans och hushållets organisationsprojekt är således ömsesidigt beroende av att berörda individer (lärare, skolledning och annan skolpersonal samt elever) fullgör individprojekt: Inom skolans organisationsprojekt utför lärare individprojektet förvärvsarbete genom att utföra de arbetsaktiviteter som definieras inom skolans organisationsprojekt. Inkomsten från förvärvsarbetet är en grund för att hushållet ska kunna nå målen med sina organisationsprojekt. Lärarens individprojekt förvärvsarbete återfinns således i skärningspunkten mellan skolans och hushållets organisationsprojekt, se figur 10. När det gäller när, var och hur länge individprojektet förvärvsarbete utförs kan konflikter uppträda mellan skolans och hushållets respektive organisationsprojekt. Konflikten kan ta sig uttryck i att lärarens lojaliteter till respektive organisationsprojekt ställs på sin spets.

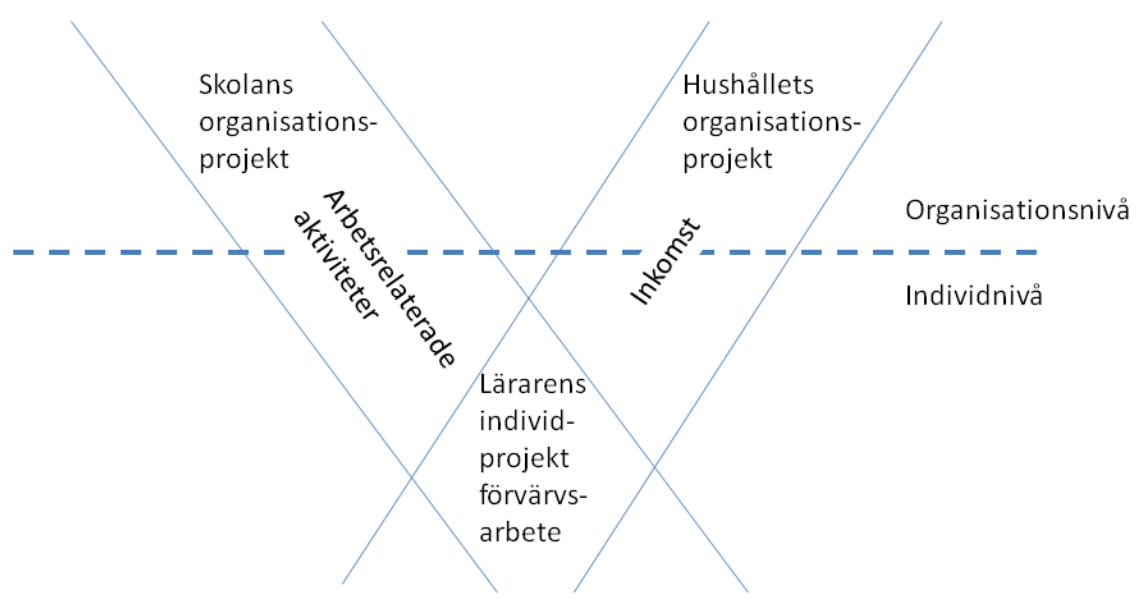




\section{VENUE}

Figur 10. Lärarens individprojekt förvärvsarbete i skärningspunkten mellan skolans och hushållets respektive organisationsprojekt. Läraren har en inkomst från att genomföra arbetsrelaterade aktiviteter inom skolans organisationsprojekt i sitt individprojekt förvärvsarbete.

Det finns andra konflikter i lärarnas tidsanvändning som yttrar sig i skolan.

Genomgången ovan av enstaka arbetsaktiviteter visade att det råder konkurrens om lärarnas tid mellan att vara rastvakt (omsorg och ordning utanför klassrummet) och lärarnas behov av återhämtning under arbetsdagen. Dessa båda aktiviteter konkurrerar om tiden under de stunder som finns mellan lektionerna i schemat.

Borde det finnas bättre möjligheter för lärare att fullgöra mer av sitt förvärvsarbete i skolan? Vad skulle det kräva? Sannolikt skulle fler lärare och mer lokaler behövas. Fler lärare behövs för att lärare i större utsträckning än idag ska kunna planera, genomföra och följa upp undervisning tillsammans. Fler lokaler behövs både för det ökade gemensamma arbetet mellan lärare och för att lärare enskilt ska kunna arbeta ostört, bland annat med sådana uppgifter som de enligt studien idag genomför hemma.

Borde det dessutom finnas fler vuxna personer i skolan som inte har pedagogisk utbildning och som kan genomföra sådana arbetsaktiviteter som exempelvis praktiska sysslor och rastvaktandet, för att ta två exempel på de mest tidskrävande arbetsaktiviteterna som nu utförs av pedagogiskt utbildad personal?

Sådana frågor kan besvaras om man på enskilda skolor kan göra gemensamma studier av den samlade tidsanvändningen bland lärare och annan skolpersonal i förhållande till skolornas utrymmen. Då kan man precisera problemen och inom skolans förutsättningar identifiera möjliga lösningar.

\section{Referenser}

Ellegård, Kajsa (1999) A time-geographical approach to the study of everyday life of individuals - a challenge of complexity. In: GeoJournal, vol 48, no 3, 1999, special issue on Actors, activities and the geographical scene. Studies on time-geography, mobility and gender. Kluwer Academic Publishers. Dordrecht.

Hägerstrand, Torsten (1985) Time-geography: Focus on the Corporeality of Man, Society, and Environment. In: The Science and Praxis of Complexity. Tokyo: The United Nations University. pp. 193-216.

Skolverket (2013a) Lärares yrkesvardag. En nationell kartläggning av grundskollärares tidsanvändning. Skolverket Rapport 385, 2013. Stockholm.

Skolverket (2013b) En tidsgeografisk studie av strukturen i lärares vardag. Skolverkets aktuella analyser, 2013. Skolverket. www.skolverket.se/publikationer

Vrotsou, Katerina (2010) Everyday mining: exploring sequences in event-based data. Dept of Science and Technology, Linköping University. Diss. 1331. Linköping. 